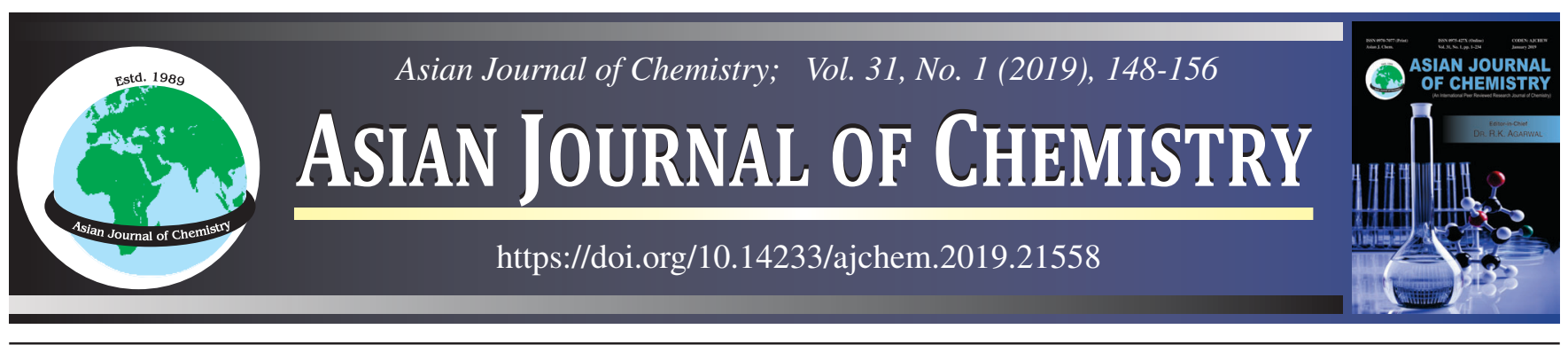

\title{
Oxidative Cleavage of DNA by Transition Metal Complexes: Synthesis, Spectral Characterization and DNA Interactions of Copper(II) Complexes with Quinquedentate Schiff Base Ligands
}

\author{
M. Pragathi ${ }^{1, *}$ and K. Hussain ReddY ${ }^{2}$
}

${ }^{1}$ Department of Chemistry, Sri Vishnu Gavimatam Government Degree College, Kalyandurg-515761, India

${ }^{2}$ Department of Chemistry, Sri Krishnadevaraya University, Anantapuramu-515003, India

*Corresponding author: E-mail: khussainreddy@yahoo.co.in; pragathi.madur@gmail.com

Designing of dinucleating ligands, with an additional donor atom that can bridge two metals in a more or less fixed geometry has rapidly developed in recent years. Part of the interest stems from the fact that the corresponding complexes are often studied as enzyme mimics. Two quinquedentate ligands have been synthesized by condensing salicylaldehyde/o-hydroxy- acetophenone with 2-hydroxy-1,3propanediamine. The ligands and their metal complexes are synthesized and characterized by physico-chemical and spectral analysis. Electrochemical behaviour of the complexes is investigated through cyclic voltammetric studies. $\mathrm{E}_{1 / 2}$ values are observed at 0.360 and $0.331 \mathrm{~V} v s . \mathrm{Ag} / \mathrm{AgCl}$ for the complexes. The non-equivalent current in cathodic and anodic peaks $\left(\mathrm{i}_{\mathrm{c}} / \mathrm{i}_{\mathrm{a}}=1.224\right.$ and 1.065 at $\left.100 \mathrm{mV} \mathrm{s} \mathrm{s}^{-1}\right)$ for metal complexes indicate quasi-reversible behaviour. Binding interactions of the dinuclear copper(II) complexes with calf thymus DNA are investigated using absorption spectrophotometry. Cleavage activities of these complexes are uncovered on a double stranded pBR plasmid DNA by using gel electrophoresis experiments in different conditions. At micromolar concentration, the ligands exhibit no significant activity, whereas the metal complexes show significantly enhanced nuclease activity due to the presence of metal ions. Copper complexes cleave DNA more effectively in the presence of oxidant. This is consistent with the increased production of hydroxyl radicals |

by cuprous ions similar to the well known "Fenton reaction".

Keywords: Oxidative cleavage of DNA, Quinquedentate ligands, Copper(II) complexes, Spectrophotometry, Fenton reaction.

\section{INTRODUCTION}

Interaction of metal complexes with nucleic acids is an exciting area of research due to their potential use as drugs, tools for biochemical and biomedical applications in gene regulation. Considerable efforts are being made to design sequence-specific DNA cleaving agents that bind DNA at any desired sequence and cleave DNA efficiently at the binding site [1-4]. Complexes that are capable of cleaving DNA hydrolytically and selectively would be highly desirable as they do not require any external agents. Several artificial metallonucleases developed to bind to DNA for the cleavage of DNA, have potential applications as therapeutic agents and as versatile replacements for nucleases as laboratory tools [5-9]. Binucleating Schiff base ligands are highly inclined to give homo and hetero polynuclear complexes with many transition metal ions and their complexes have been of interest for many years [10-15]. When designing dinuclear metal complexes the choice of the ligand system is of prime importance. It should be capable of incorporating two metal ions. Ligands which afford complexes with the metal ions sharing at least one donor atom (the so-called compartmental ligands) seem to be appropriate for this purpose.

The design of dinucleating ligands, with an additional donor atom that can bridge two metals in a more or less fixed geometry has rapidly developed in recent years. Part of the interest stems from the fact that the corresponding complexes are often studied as enzyme mimics [16-18].

Although metal complexes derived using other quinquedentate ligands have been reported [17-19] in the past. The investigations on DNA binding and cleavage activities of such complexes are not reported so far. In continuation of our ongoing research

This is an open access journal, and articles are distributed under the terms of the Creative Commons Attribution-NonCommercial 4.0 International (CC BY-NC 4.0) License, which allows others to copy and redistribute the material in any medium or format, remix, transform, and build upon the material, as long as appropriate credit is given and the new creations are licensed under the identical terms. 
work on metal DNA interactions [20-31], herein we report the synthesis, characterization and DNA interaction of copper(II) complexes derived from condensation of salicylaldehyde/ $o$-hydroxyacetophenone and 2-hydroxy-1,3-propanediamine.

\section{EXPERIMENTAL}

Salicylaldehyde, 2-hydroxyacetophenone and 2-hydroxy1,3-propanediamine used in preparation of ligands were of reagent grade (Sigma-Aldrich) and were used without further purification. Metal salts used for the synthesis of metal complexes were of reagent grade (Merck). Solvents used in the present study were distilled before use. Calf thymus DNA and plasmid pBR 322 were purchased from Genie Bio Labs, Bangalore, India. All other chemicals were of AR grade and used without further purification.

Magnetic measurements of all the copper(II) complexes at $298 \mathrm{~K}$ were obtained on a Faraday's magnetic susceptibility balance (Sherwood Scientific, Cambridge, UK). High purity pentahydrated copper sulfate was used as standard. The conductance measurements at $298 \pm 2 \mathrm{~K}$ in dry and purified dimethylformamide were made on $\mathrm{CM}$ conductivity cell (model 162 Elico). Infrared spectra in $\mathrm{KBr}$ disc were recorded in the range $4000-400 \mathrm{~cm}^{-1}$ on a Perkin-Elmer spectrum 100 spectrometer. Electronic spectra were recorded in N,N-dimethyl formamide on a Perkin-Elmer UV Lamda-50 spectrophotometer. Elemental analyses were carried out with a Heraeus Vario EL III Carlo Erba 1108 instrument. Mass spectra of the ligands were recorded on Jeol GC MATE II GC-Mass spectrometer in $\mathrm{EI}^{+}$ionization mode. ${ }^{1} \mathrm{H}$ NMR spectra were recorded at 400.00 MHz on a Avance- 400 Bruker spectrometer at CDRI, Lucknow. ESR spectra were recorded in solid state and in DMF at $298 \mathrm{~K}$ and at liquid nitrogen temperature (L.N.T) on a Varian E-112 spectrometer with $100 \mathrm{KHz}$ field modulation. The $\mathrm{g}_{\|}$and $\mathrm{g}_{\perp}$ values are computed from the spectrum using tetracyanoethylene (TCNE) free radical as 'g'. Cyclic voltammetry was performed with a CH Instruments 660C electrochemical analyzer and a conventional type electrode, $\mathrm{Ag} / \mathrm{AgCl}$ reference electrode, glassy carbon working electrode and platinum counter electrode. Nitrogen was used as purge gas and all solutions were prepared in DMF containing 0.1 M concentration in tetrabutylammoniumhexaflorophosphate $\left(\mathrm{TBAPF}_{6}\right)$. DNA cleavage activities were performed on a UVI-tech-UK Xplorer Gel documentation system.

Synthesis of ligands: Ligands were prepared according to literature methods [19]. The ligand [2-hydroxy-(1,3-diiminopropyl)]bisphenol $\left(\mathrm{HDPH}_{3}\right)$ was synthesized by the refluxion of salicylaldehyde ( $20 \mathrm{mmol}, 2.1 \mathrm{~mL})$ with a methanolic solution of 1,3-diaminopropan-2-ol ( $0.9 \mathrm{~g}, 10 \mathrm{mmol})$ for $30 \mathrm{~min}$. Whereas the ligand [2-hydroxy-(1,3-diiminopropyl)2,2'-methyl] bisphenol $\left(\mathrm{HDMPH}_{3}\right)$ was synthesized by the reaction of 2-hydroxyacetophenone (20 mmol, $2.4 \mathrm{~mL}$ ) and 1,3-diaminopropan-2ol $(0.9 \mathrm{~g}, 10 \mathrm{mmol})$. The bright yellow crystalline Schiff bases are separated out on slow evaporation of the solvent. Ligands were further washed with methanol and dried in vacuoo. $\mathrm{HDPH}_{3}$ : Yield: $82 \%$; m.p.: 99-101 ${ }^{\circ} \mathrm{C}$. Anal. (\%) Calc. (found): C-68.32 (68.44); H-5.98 (6.08); N-9.51(9.39); O-16.19(16.09); $\mathrm{HDMPH}_{3}$ : Yield: $88 \%$; m.p.: $174-176{ }^{\circ} \mathrm{C}$. Anal. $(\%)$ Calc. (found): C-70.12 (69.92); H-6.68 (6.79); N-8.46 (8.58); O14.74 (14.71); Fig. 1 gives the general structure of ligands. The

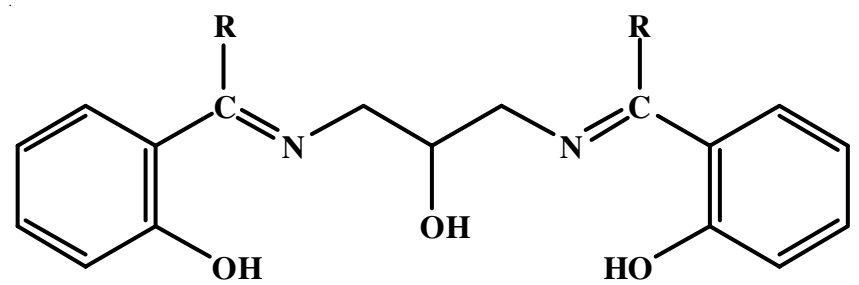

where, $\mathrm{R}=\mathrm{H}$ \{2-hydroxy-(1,3-diiminopropyl) $\}$ bisphenol $\left(\mathrm{HDPH}_{3}\right)$ $\mathrm{R}=\mathrm{CH}_{3}$ \{2-hydroxy-(1,3-diiminopropyl)2,2'-methyl $\}$ bisphenol $\left(\mathrm{HDMPH}_{3}\right)$

Fig. 1. General structure of quinquedentate ligands

infrared spectra of $\mathrm{HDPH}_{3}$ and $\mathrm{HDMPH}_{3}$ showed the bands at $\left(\mathrm{cm}^{-1}\right): 3512,3446 ; 1633,1612 ; 2896,2925 ; 1275,1279$ assigned to $v(\mathrm{OH}) ; v(\mathrm{C}=\mathrm{N}) ; v($ aromatic $\mathrm{C}-\mathrm{H})$; and $v(\mathrm{C}-\mathrm{O})$ stretching vibrations, respectively. ${ }^{1} \mathrm{H}$ NMR: $\mathrm{HDPH}_{3}: \delta(13.2)$ (singlet $2 \mathrm{H}), \delta(8.4)$ (singlet $1 \mathrm{H}), \delta(6.4-7.2)$ (multiplet $8 \mathrm{H}$ ), $\delta(4.2)$ (singlet $2 \mathrm{H}$ ) and $\delta(3.9)$ (multiplet $4 \mathrm{H}$ ) and $\delta(3.8)$ (multiplet $1 \mathrm{H})$ assigned, respectively to phenolic $-\mathrm{OH}$, alcoholic $\mathrm{OH}$, phenyl $\mathrm{H}, \mathrm{N}=\mathrm{CH}-,-\mathrm{CH}_{2}$ - and $\mathrm{CH}-\mathrm{OH}$ (methine) protons, respectively and $\mathrm{HDMPH}_{3}: \delta(14.1)$ (singlet $\left.2 \mathrm{H}\right), \delta(8.2)$ (singlet $1 \mathrm{H}$ ), $\delta(6.8-7.2)$ (multiplet $8 \mathrm{H}), \delta(4.4)$ (singlet $2 \mathrm{H}$ ) and $\delta(3.7)$ (multiplet $1 \mathrm{H}), \delta(2.4)($ doublet $2 \mathrm{H})$ and $\delta(1.6)$ (singlet $6 \mathrm{H}$ ) assigned, respectively to phenolic - $\mathrm{OH}$, alcoholic $\mathrm{OH}$, phenyl $\mathrm{H}, \mathrm{N}=\mathrm{CH}-, \mathrm{CH}-\mathrm{OH}$ (methine), $-\mathrm{CH}_{2}-$ and $-\mathrm{CH}_{3}$ protons, respectively. GC-mass spectra of $\mathrm{HDPH}_{3}$ and $\mathrm{HDMPH}_{3}$ show molecular ion peaks at $(\mathrm{m} / \mathrm{z}) 298$ and 326, respectively. GC-MS Spectrum of $\mathrm{HDMPH}_{3}$ is shown in Fig. 2 .

Synthesis of copper(II) complexes: To a stirring methanolic solution of copper(II) acetate monohydrate $(1.99 \mathrm{~g}, 10 \mathrm{mmol})$, a hot methanolic solution of $\mathrm{HDPH}_{3}(5 \mathrm{mmol}, 1.49 \mathrm{~g}) / \mathrm{HDMPH}_{3}$ ( $5 \mathrm{mmol}, 1.63 \mathrm{~g}$ ) was added drop-wise with constant stirring. The contents were stirred magnetically for $3 \mathrm{~h}$. The contents were then filtered. Shining dark green coloured crystalline products were obtained on slow evaporation of the solvent. The complexes were washed with methanol and dried in vacuoo. [Cu$\left.{ }_{2}\left(\mathrm{CH}_{3} \mathrm{COO}\right)(\mathrm{HDP})\right]$ : Yield: $62 \%$; m.p.: $218-220{ }^{\circ} \mathrm{C}$ (D). [ $\left.\mathrm{Cu}_{2}\left(\mathrm{CH}_{3} \mathrm{COO}\right)(\mathrm{HDMP})\right]$ : Yield: $58 \%$; m.p.: $268-270^{\circ} \mathrm{C}$ (D). LC-MS spectra of copper(II) complexes showed molecular ion peaks corresponding to their calculated molecular weights (Fig. 3). The peak at $m / z=509.21$ (cal. 509.50) represents the molecular ion peak of the complex $\mathrm{Cu}_{2}\left(\mathrm{CH}_{3} \mathrm{COO}\right) \mathrm{HDMP}$. The LC-MS spectrum of $\mathrm{Cu}_{2}\left(\mathrm{CH}_{3} \mathrm{COO}\right) \mathrm{HDP}$ shows peak at $\mathrm{m} / \mathrm{z}=$ 481.98 (cal. 481.45) related to molecular ion peak of the complex $\mathrm{Cu}_{2}\left(\mathrm{CH}_{3} \mathrm{COO}\right) \mathrm{HDP}$. Analytical data of complexes are given in Table-1.

DNA binding experiments: Binding interactions of the complexes with DNA were carried out in tris-buffer. Solution of calf thymus-DNA (CT-DNA) in $(0.5 \mathrm{mM} \mathrm{NaCl} / 5 \mathrm{mM}$ Tris$\mathrm{HCl} ; \mathrm{pH}=7.0$ ) buffer gave absorbance ratio at 260 and 280 $\mathrm{nm}$ of 1.8 indicating that the DNA was sufficiently free of proteins. The DNA concentration per nucleotide was determined by absorption coefficient $\left(6600 \mathrm{dm}^{3} \mathrm{~mol}^{-1} \mathrm{~cm}^{-1}\right)$ at 260 $\mathrm{nm}$. Stock solutions stored at $4{ }^{\circ} \mathrm{C}$ were used after not more than 4 days. The electronic spectra of metal complexes were monitored in the absence and presence of CT-DNA. Absorption titrations were performed by maintaining the metal complex concentration $5 \times 10^{-5} \mathrm{M}$ and varying the nucleic acid concentration $\left(0-19 \times 10^{-8} \mathrm{M}\right)$. Absorption spectra were recorded after each successive addition of DNA solution. The intrinsic binding 


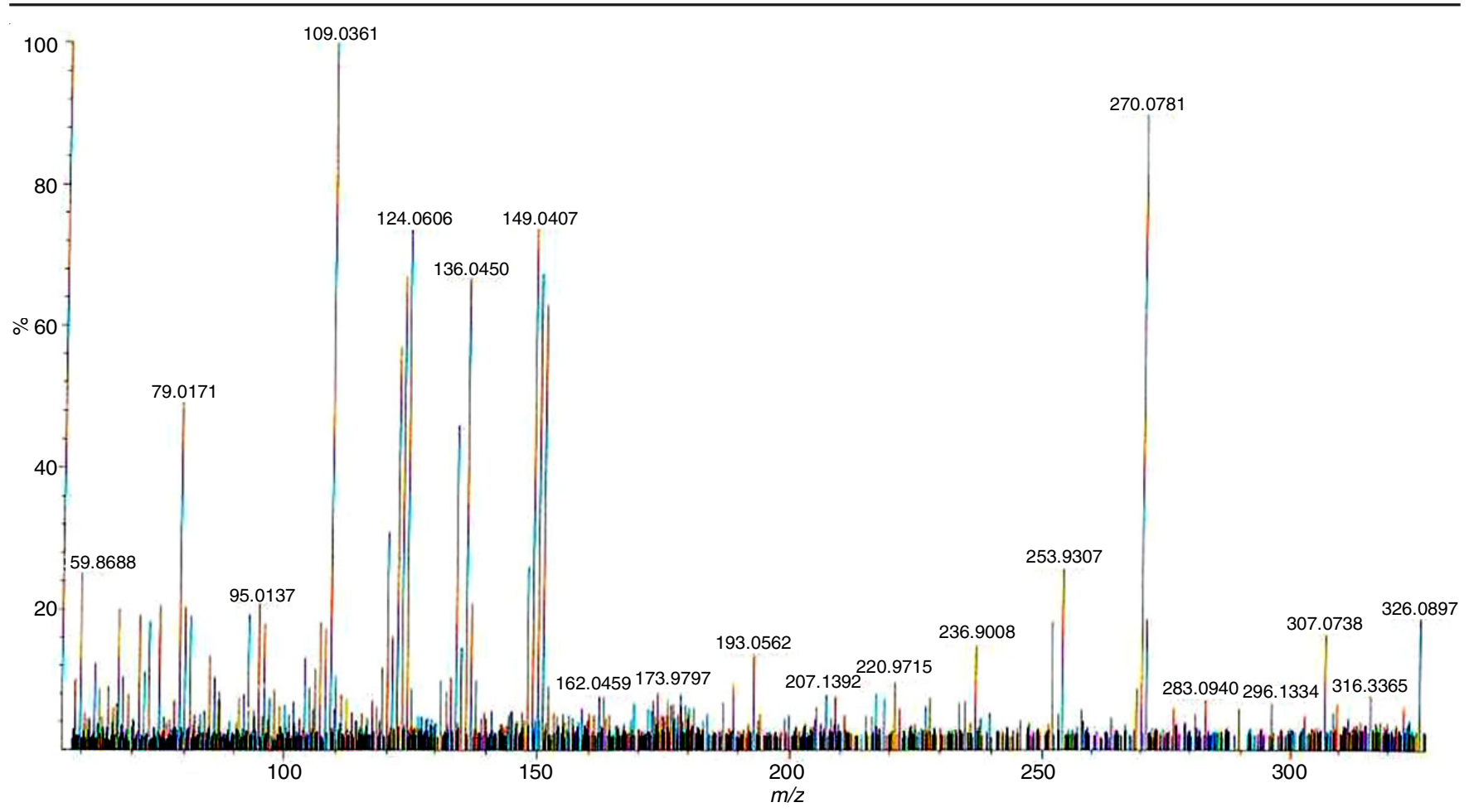

Fig. 2. GC-MS spectrum of $\mathrm{HDMPH}_{3}$

TABLE-1

PHYSICO-CHEMICAL AND ANALYTICAL DATA OF COPPER(II) COMPLEXES

\begin{tabular}{|c|c|c|c|c|c|c|c|c|c|}
\hline \multirow{2}{*}{ Complex } & \multirow{2}{*}{$\begin{array}{l}\text { Colour } \\
\text { (Yield \%) }\end{array}$} & \multirow{2}{*}{$\begin{array}{l}\text { Decomposition } \\
\text { point }\left({ }^{\circ} \mathrm{C}\right)\end{array}$} & \multirow{2}{*}{$\begin{array}{l}\text { Molar conductance } \\
\left(\Omega^{-1} \mathrm{~cm}^{-2} \mathrm{~mol}^{-1}\right)\end{array}$} & \multirow{2}{*}{$\begin{array}{r}\mu_{\text {eff }} \\
(\mathrm{BM})\end{array}$} & \multirow{2}{*}{ m.w. * } & \multicolumn{4}{|c|}{ Elemental analysis (\%): Found (Calcd.) } \\
\hline & & & & & & $\mathrm{C}$ & $\mathrm{H}$ & $\mathrm{N}$ & $\mathrm{Cu}$ \\
\hline $\mathrm{Cu}_{2}\left(\mathrm{CH}_{3} \mathrm{COO}\right) \mathrm{HDP}$ & $\begin{array}{l}\text { Dark green } \\
\quad(62)\end{array}$ & $218-220$ & 8.22 & 1.06 & $\begin{array}{c}481.98 \\
(481.45)\end{array}$ & $\begin{array}{c}47.36 \\
(47.40)\end{array}$ & $\begin{array}{c}3.81 \\
(3.77)\end{array}$ & $\begin{array}{c}5.66 \\
(5.82)\end{array}$ & $\begin{array}{c}26.48 \\
(26.40)\end{array}$ \\
\hline $\mathrm{Cu}_{2}\left(\mathrm{CH}_{3} \mathrm{COO}\right) \mathrm{HDMP}$ & $\begin{array}{l}\text { Dark green } \\
\quad(58)\end{array}$ & $268-270$ & 6.34 & 1.26 & $\begin{array}{c}509.21 \\
(509.50)\end{array}$ & $\begin{array}{c}49.78 \\
(49.50)\end{array}$ & $\begin{array}{c}4.22 \\
(4.35)\end{array}$ & $\begin{array}{c}5.74 \\
(5.50)\end{array}$ & $\begin{array}{c}24.64 \\
(24.94)\end{array}$ \\
\hline
\end{tabular}

*Determined using LC-MS.

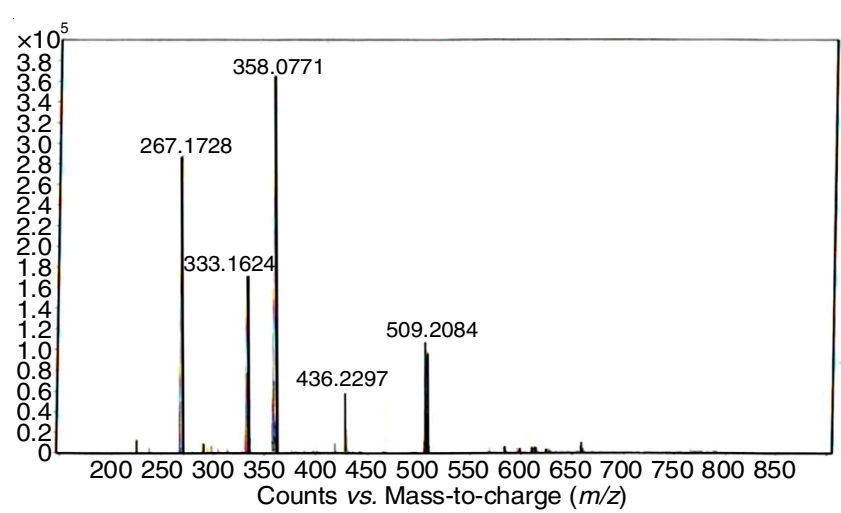

Fig. 3. LC-MS spectrum of $\mathrm{Cu}_{2}\left(\mathrm{CH}_{3} \mathrm{COO}\right)$ HDMP

constant $\left(\mathrm{K}_{\mathrm{b}}\right)$ was calculated by using the equation, [DNA]/ $\left(\varepsilon_{a}-\varepsilon_{f}\right)=[D N A] /\left(\varepsilon_{b}-\varepsilon_{f}\right)+1 / K_{b}\left(\varepsilon_{b}-\varepsilon_{f}\right)$, where [DNA] is the molar concentration of DNA in base pairs, $\varepsilon_{\mathrm{a}}, \varepsilon_{\mathrm{b}}$ and $\varepsilon_{\mathrm{f}}$ are apparent extinction coefficient $\left(\mathrm{A}_{\mathrm{obs}} /[\mathrm{M}]\right)$, the extinction coefficient for the metal (M) complex in the fully bound form and the extinction coefficient for free metal (M), respectively.

DNA cleavage experiments: The extent of cleavage of DNA by ligands and their copper(II) complexes was monitored using agarose gel electrophoresis with pBR 322 DNA. After incubation for $30 \mathrm{~min}$ at $37^{\circ} \mathrm{C}$, the samples were added to the loading buffer containing $0.25 \%$ bromophenol blue $+0.25 \%$ xylene cyanol $+30 \%$ glycerol and solutions were loaded on $0.8 \%$ agarose gel containing $100 \mu \mathrm{g}$ of ethidium bromide. Electrophoresis was performed at $75 \mathrm{~V}$ in TBE buffer until the bromophenol blue reached to $3 / 4$ of the gel. Bands were visualized by UV transilluminator and photographed. The efficiency of DNA cleavage was measured by determining the ability of the complex to form open circular (OC) or nicked circular (NC) DNA from its supercoiled (SC) form. The reactions were carried out under different conditions.

\section{RESULTS AND DISCUSSION}

The ligands containing two imino groups and three hydroxyl groups have been synthesized and characterized. Copper(II) complexes of these ligands are stable at room temperature, non-hygroscopic, insoluble in water and methanol, but readily soluble in DMF and DMSO. In spite of several repeated efforts the complexes could not be isolated as single crystals suitable for XRD. Hence, the complexes have been characterized based on the physico-chemical analyses and spectral data. Low molar conductivity values $\left(<20 \Omega^{-1} \mathrm{~cm}^{-2} \mathrm{~mol}^{-1}\right)$ (Table-1) of present copper(II) complexes suggest non-electrolytic nature of the complexes [32]. The magnetic moment values of copper complexes (1.06 and 1.26 BM) are found to be sub-normal to spin 
only value [33-35]. The data suggest the presence of antiferromagnetically coupled copper centers in the complexes.

In the electronic spectra of $\mathrm{Cu}_{2}\left(\mathrm{CH}_{3} \mathrm{COO}\right) \mathrm{HDP}$ and $\mathrm{Cu}_{2}\left(\mathrm{CH}_{3} \mathrm{COO}\right) \mathrm{HDMP}$ complexes intense band are observed at 37037 and $37174 \mathrm{~cm}^{-1}$, respectively, which are attributed to intra ligand $\pi-\pi^{*}$ aromatic ring and imine moiety. The respective bands at 27027 and $27472 \mathrm{~cm}^{-1}$ are assigned to metal to ligand charge transfer transition $(\mathrm{M} \rightarrow \mathrm{LCT})$. Typical electronic spectrum of $\mathrm{Cu}_{2}\left(\mathrm{CH}_{3} \mathrm{COO}\right) \mathrm{HDP}$ is shown in Fig. 4. The corresponding low intensity broad structured bands at 15600 and $5898 \mathrm{~cm}^{-1}$ are assigned to $d-d$ transitions. Since the molar absorptivity values $\left(\pi-\pi^{*} \sim 1700, \mathrm{CT} \sim 760, d-d \sim 300 \mathrm{~L} \mathrm{~mol}^{-1} \mathrm{~cm}^{-1}\right)$ are quite high, the bands assigned ${ }^{2} \mathrm{~T}_{2} \rightarrow{ }^{2}$ E electronic transition in favour of tetrahedral structure.

Infrared spectra of the complexes in $\mathrm{KBr}$ disc were recorded in the range $4000-400 \mathrm{~cm}^{-1}$ on a Perkin-Elmer spectrum 100 spectrometer. The donor sites of ligands have been identified from infrared spectral studies. The $v(\mathrm{OH})$ stretching vibrations are observed in 3512-3446 $\mathrm{cm}^{-1}$ region in ligands. These absorption bands are absent in complexes suggesting the deprotonation of all the three $-\mathrm{OH}$ groups in complex formation. Thus, the ligand is triply deprotonated in the complex formation. The $\mathrm{C}=\mathrm{N}$ (imine) vibrations are observed at 1633 and $1612 \mathrm{~cm}^{-1}$ in the IR spectra of ligands. These bands are shifted to lower wave number in IR spectra of the complexes suggesting the participation of azomethine nitrogen atom in coordination with metal atom [36]. Strong bands observed at 1552 and $1546 \mathrm{~cm}^{-1}$ are due to the presence of bridging acetato group [23,37]. Stretching vibrations of free or non-coordinated acetate ion occurs in the range $1160-1115 \mathrm{~cm}^{-1}$ whereas the terminal acetate shows vibrational peak in $1060-1040 \mathrm{~cm}^{-1}$ region. The lowering of the position of the phenolic $\mathrm{C}-\mathrm{O}$ bands in the complexes indicates the formation of covalent bond between metal and oxygen [38]. The spectra of the copper(II) complexes show bands which could be assigned due to bridging coordination mode of the acetate anion. The asymmetric $\left(v_{\text {asy }}\right)$ and the symmetric $\left(v_{\text {sym }}\right)$ stretching vibrations of the acetate and in particular, their differences, $\Delta v=v_{\text {asy }}-v_{\text {sym }}$ have been used as empirical indicators of coordination modes of the acetate group. According to Deacon and Philip [39], a difference larger than 200
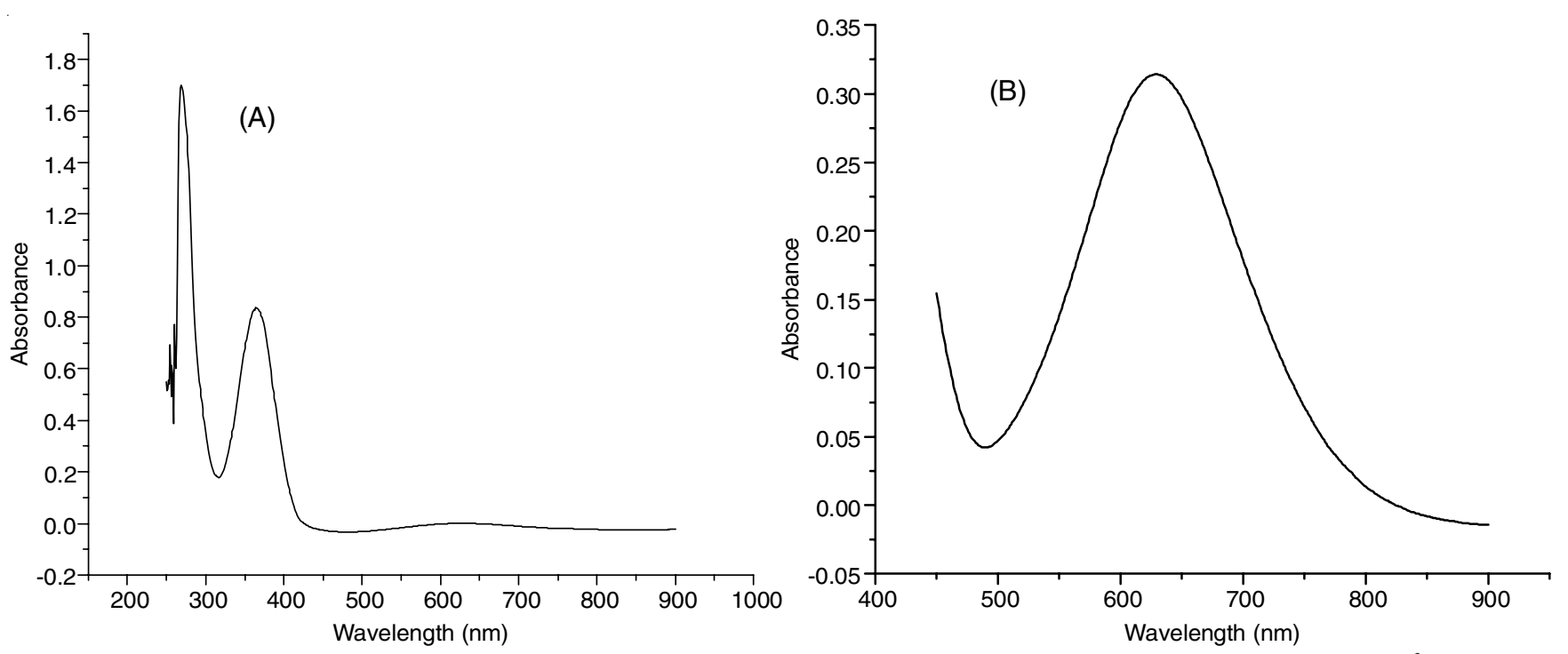

$\mathrm{cm}^{-1}$ indicates monodentate coordination, whereas difference smaller than $200 \mathrm{~cm}^{-1}$ indicates bridging coordination mode. In the complexes, the frequencies of vibration $v_{\text {asy }}(\mathrm{COO})$ appears in the range at 1552 and $1546 \mathrm{~cm}^{-1}$ while those characteristic of the $v_{\mathrm{sym}}(\mathrm{COO})$, appeared at 1409 and $1387 \mathrm{~cm}^{-1}$. A value of Dv $<200 \mathrm{~cm}^{-1}$, indicates bridging coordination mode of acetate group [40]. In the IR spectra of all the complexes aromatic ring vibrations and $\mathrm{C}=\mathrm{C}$ vibrations are not much affected. The $\mathrm{cm}^{-1}$ and $412-406 \mathrm{~cm}^{-1}$ are assigned to $v(\mathrm{M}-\mathrm{O})$ and $v(\mathrm{M}-\mathrm{N})$, respectively [41].

ESR spectra studies: ESR spectra of copper(II) complexes were recorded at room temperature and at liquid nitrogen temperature (LNT) in both solution ((DMF) and solid state. Typical ESR spectra of $\mathrm{Cu}_{2}\left(\mathrm{CH}_{3} \mathrm{COO}\right) \mathrm{HDP}$ in powder state at $300 \mathrm{~K}$, at liquid nitrogen temperature, in DMF solution at 300 $\mathrm{K}$ and at liquid nitrogen temperature are shown in Fig. 5. The spin Hamiltonian and orbital reduction parameters of copper complexes are given in Tables 2(a) and 2(b). The $g_{\|}$and $g_{\perp}$ values are computed from the spectrum using tetracyanoethylene (TCNE) free radical as ' $\mathrm{g}$ ' marker. It is significant from the data that the observed $g_{\|}$values for all these copper complexes are less than 2.3 suggesting covalent character of the metalligand bonding [39]. The g tensor values of copper(II) complexes can be used to derive the ground state. In square planar complexes, the unpaired electron lies in the $\mathrm{d}_{\mathrm{x}^{2}-\mathrm{y}^{2}}$ orbitals giving ${ }^{2} \mathrm{~B}_{1 \mathrm{~g}}$ as the ground state with $\mathrm{g}_{\|}>\mathrm{g}_{\perp}>2.0023$, while the unpaired electron lies in the $\mathrm{d}_{\mathrm{z}^{2}}$ orbital giving ${ }^{2} \mathrm{~A}_{1 \mathrm{~g}}$ as the ground state with $g_{\perp}>g_{\|}>2.0023$. From the observed values of complexes at $300 \mathrm{~K}$ and $77 \mathrm{~K}$ in solid state spectrum it is clear that $g_{\|}>g_{\perp}$ $>2.0023$ which suggests the fact that the unpaired electron lies predominantly in the $\mathrm{d}_{\mathrm{x}^{2}-\mathrm{y}^{2}}$ orbital [42]. The $\mathrm{g}_{\mathrm{av}}$ value for these complexes is greater than 2 indicating covalent nature of the metal-ligand bond [43].

In the solid state, similar spectra of these complexes at $77 \mathrm{~K}$ and $300 \mathrm{~K}$ indicates that the geometry around copper(II) ion is unaffected on cooling to liquid nitrogen temperature. In these conditions the axial symmetry parameter $\mathrm{G}$, which measures the interaction between copper centres in unit cell is calculated from the following equation: non-ligand absorption bands occurring in the regions 509-506

Fig. 4. Electronic spectra of $\mathrm{Cu}_{2}\left(\mathrm{CH}_{3} \mathrm{COO}\right) \mathrm{HDP}(\mathrm{A})$ in DMF solvent and (B) spectrum of high concentration $\left(1 \times 10^{-3} \mathrm{M}\right)$ 


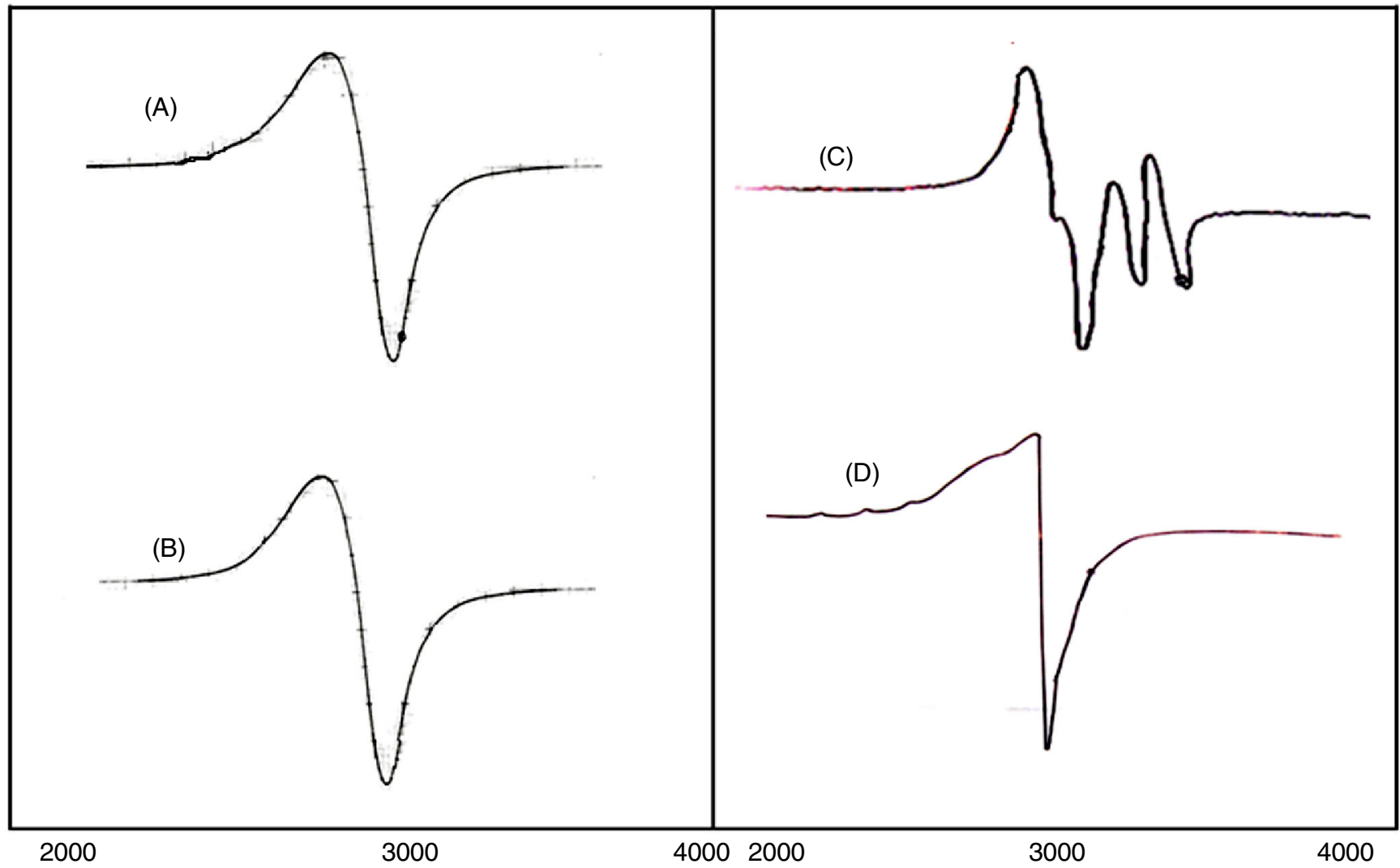

Fig. 5. (A) X-band powder ESR spectra of $\mathrm{Cu}_{2}\left(\mathrm{CH}_{3} \mathrm{COO}\right) \mathrm{HDP}$ at $300 \mathrm{~K}$, (B) at LNT, (C) in DMF solution at $300 \mathrm{~K}$ and (D) at LNT in DMF solution

TABLE-2(a)

SPIN HAMILTONIAN AND ORBITAL REDUCTION PARAMETERS OF COPPER COMPLEXES IN POWDER STATE

\begin{tabular}{lcccc|cccc}
\hline \multirow{2}{*}{\multicolumn{1}{c}{ Complex }} & \multicolumn{4}{c}{ At room temperature } & \multicolumn{4}{c}{ At liquid nitrogen temperature (LNT) } \\
\cline { 2 - 9 } & $\mathrm{g}_{\|}$ & $\mathrm{G}_{\perp}$ & $\mathrm{g}_{\mathrm{av}}$ & $\mathrm{G}$ & $\mathrm{g}_{\|}$ & $\mathrm{G}_{\perp}$ & $\mathrm{g}_{\mathrm{av}}$ & $\mathrm{G}$ \\
\hline $\mathrm{Cu}_{2}\left(\mathrm{CH}_{3} \mathrm{COO}\right) \mathrm{HDP}$ & 2.114 & 2.077 & 2.089 & 1.495 & 2.117 & 2.081 & 2.093 \\
$\mathrm{Cu}_{2}\left(\mathrm{CH}_{3} \mathrm{COO}\right) \mathrm{HDMP}$ & 2.136 & 2.098 & 2.110 & 1.397 & 2.138 & 2.101 & 2.113 & 1.457 \\
\hline
\end{tabular}

TABLE-2(b)

SPIN HAMILTONIAN AND ORBITAL REDUCTION PARAMETERS OF COPPER COMPLEXES IN DMF SOLUTION

\begin{tabular}{lcccccccccccc}
\hline \multicolumn{1}{c}{ Complex } & $\mathrm{g}_{\|}$ & $\mathrm{g}_{\perp}$ & $\mathrm{g}(\mathrm{av})$ & $\mathrm{G}$ & $\lambda$ & $\mathrm{K}_{\|}$ & $\mathrm{K}_{\perp}$ & $\begin{array}{c}\mathrm{A}_{\|} \\
\left(\mathrm{cm}^{-1}\right)\end{array}$ & $\begin{array}{c}\mathrm{A}_{\perp} \\
\left(\mathrm{cm}^{-1}\right)\end{array}$ & $\mathrm{A}_{\mathrm{av}}$ & $\mathrm{g}_{\|} / \mathrm{A}_{\|}$ & $\alpha^{2}$ \\
\hline $\mathrm{Cu}_{2}\left(\mathrm{CH}_{3} \mathrm{COO}\right) \mathrm{HDP}$ & 2.124 & 2.068 & 2.086 & 1.852 & 335 & 0.841 & 1.236 & 0.0182 & 0.0128 & 0.0146 & 117 & 0.315 \\
$\mathrm{Cu}_{2}\left(\mathrm{CH}_{3} \mathrm{COO}\right) \mathrm{HDMP}$ & 2.148 & 2.082 & 2.104 & 1.828 & 413 & 0.837 & 1.238 & 0.0190 & 0.0125 & 0.0146 & 113 & 0.308 \\
\hline
\end{tabular}

$$
\mathrm{G}=\left[\mathrm{g}_{\|}-2.0023 / \mathrm{g}_{\perp}-2.0023\right]
$$

The calculated $G$ values are found to be less than 4 for the copper complexes suggesting that there are considerable interactions between metal ions in the solid complex [44]. The broad ESR spectra clearly reveal that there is strong antiferromagnetic interaction between two metal ions in the complexes. This antiferromagnetic coupling occurs due to the quenching of the spin of electrons of one metal ion by the adjacent metal ion [37].

ESR spectra were recorded in DMF at room temperature and liquid nitrogen temperature to obtain more accurate molecular values by giving four hyperfine signals for all the complexes. The ESR parameters $\left(\mathrm{g}_{\|}, \mathrm{g}_{\perp}, \mathrm{A}_{\|}, \mathrm{A}_{\perp}\right)$ of the complexes and the energies of $d-d$ transitions are used [45-47] to evaluate spin-orbit coupling constant $(\lambda)$ and the orbital reduction parameters $\left(K_{\|}, K_{\perp}\right)$. The trend $g_{\|}>g_{\perp}>g_{e}$ (2.0023) observed for these complexes suggests that the unpaired electron is localized in $\mathrm{d}_{\mathrm{x}^{2}-\mathrm{y}^{2}}$ orbital [48] of the copper(II) ion. For both copper(II) complexes the lowest $g$ value greater than 2.0023 is also consistent with $\mathrm{a} \mathrm{d}_{\mathrm{x}^{2}-\mathrm{y}^{2}}$ ground state. The spin-orbit coupling constant $(\lambda)$ value is calculated using the relation, $\mathrm{g}_{\mathrm{av}}=\left(\mathrm{g}_{\|}+2 \mathrm{~g}_{\perp}\right) 1 / 3$ and $\mathrm{g}_{\mathrm{ave}}=2(1-2 \lambda / 10 \mathrm{Dq})$, is less than the free copper(II) $\left(832 \mathrm{~cm}^{-1}\right)$ which also supports covalent character of $\mathrm{M}-\mathrm{L}$ bond. The observed $\mathrm{K}_{\|}<\mathrm{K}_{\perp}$ relation in all the complexes indicates the presence of in plane $\pi$-bonding [49]. The in-plane bonding parameter $\alpha^{2}$ values are calculated using the following relation:

$$
\alpha^{2}=-\left(\mathrm{A}_{\|} / 0.036\right)+\left(\mathrm{g}_{\|}-2.0023\right)+3 / 7\left(\mathrm{~g}_{\perp}-2.0023\right)+0.04
$$

The empirical factor $\mathrm{g}_{\| /} \mathrm{A}_{\|}\left(\mathrm{cm}^{-1}\right)$, is an index of tetrahedral distortion. In these two complexes, $\mathrm{g}_{\| /} \mathrm{A}_{\|}$falls in the range 113- 
$117 \mathrm{~cm}$ corresponding to a copper(II) center with medium distortion [50].

Based on molar conductance, magnetic moment, GC-MS, electronic, FT-IR and ESR spectral data the following general structure (Fig. 6) is assigned to copper(II) complexes of quinquedentate Schiff base ligands.

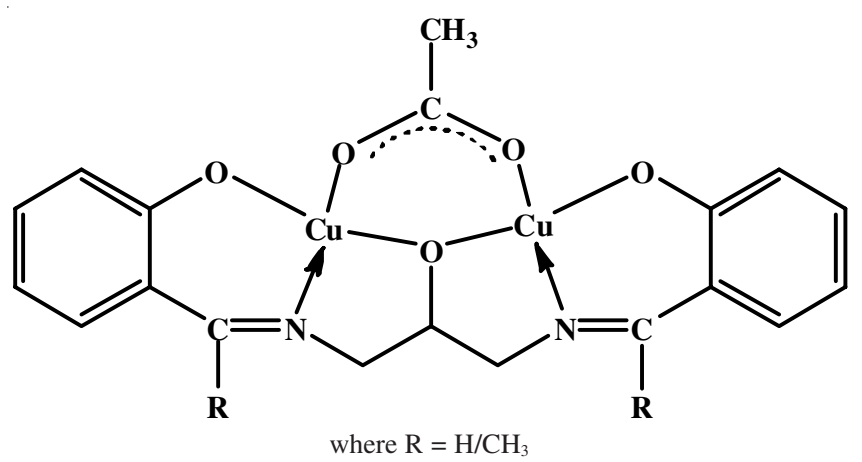

Fig. 6. Tentative structure of the acetato bridged dinuclear copper complex

Electrochemical studies: Redox behaviour of the copper(II) complexes has been investigated by cyclic voltammetry in DMF using $0.1 \mathrm{M}$ tetrabutylammonium hexaflourophosphate as supporting electrolyte. The cyclic voltammetric profile of $\mathrm{Cu}_{2}\left(\mathrm{CH}_{3} \mathrm{COO}\right) \mathrm{HDEP}$ is given in Fig. 7. The electrochemical data of the complexes are presented in Table-3.

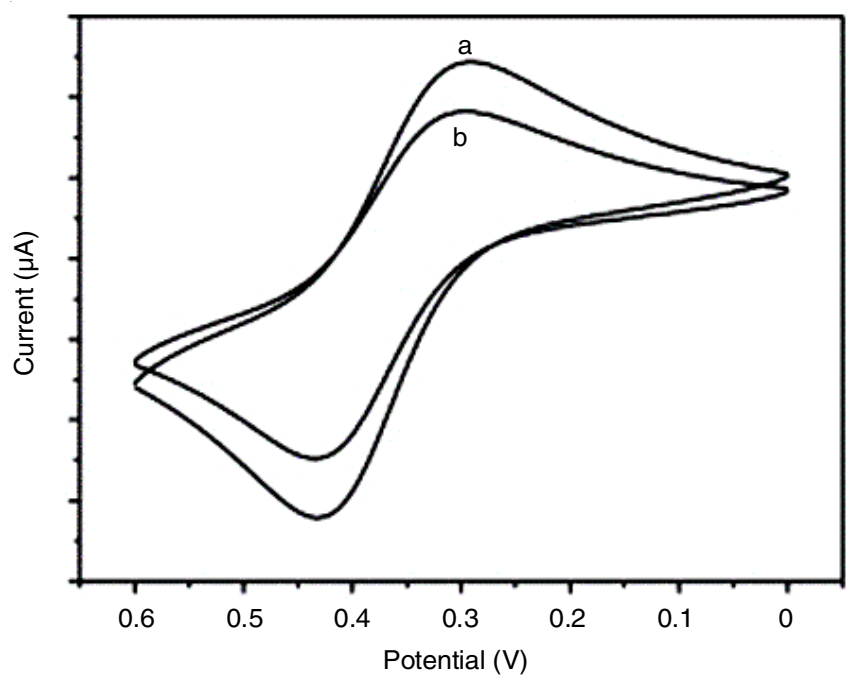

Fig. 7. Cyclic voltammetric profile of $\mathrm{Cu}_{2}\left(\mathrm{CH}_{3} \mathrm{COO}\right) \mathrm{HDMP}$ at different scan rates (a) $100 \mathrm{mV} \mathrm{s}^{-1}$ and (b) $50 \mathrm{mV} \mathrm{s}^{-1}$

Repeated scans at various scan rates suggest the presence of stable redox species in solution. $\mathrm{E}_{1 / 2}$ values are observed at 0.360 and $0.331 \mathrm{~V} v$ s. $\mathrm{Ag} / \mathrm{AgCl}$ for the complexes $\mathrm{Cu}_{2}\left(\mathrm{CH}_{3} \mathrm{COO}\right) \mathrm{HDP}$ and $\mathrm{Cu}_{2}\left(\mathrm{CH}_{3} \mathrm{COO}\right) \mathrm{HDMP}$, respectively. It may be inferred that $\mathrm{Cu}$ (II) complexes undergo reduction to their respective $\mathrm{Cu}(\mathrm{I})$ complexes. The non-equivalent current in cathodic and anodic peaks $\left(\mathrm{i}_{\mathrm{c}} / \mathrm{i}_{\mathrm{a}}=1.224\right.$ and 1.065 at $\left.100 \mathrm{mV} \mathrm{s}^{-1}\right)$ for complexes indicate quasi-reversible behaviour [51]. The difference $\Delta \mathrm{E}_{\mathrm{p}}$ $=\mathrm{E}_{\mathrm{pc}}-\mathrm{E}_{\mathrm{pa}}$ in all the complexes exceeds the Nerstian requirement $59 / \mathrm{n} \mathrm{mV}(\mathrm{n}=$ number of electrons involved in oxidation reduction) which suggests quasi-reversible character associated with a considerable reorganization of the coordination sphere during electron transfer [52]. The complexes have large separation (129 and $154 \mathrm{mv}$ ) between anodic and cathodic peaks indicating quasi-reversible character. The $\mathrm{E}_{1 / 2}$ values of copper complexes are inversely related to the size of the complex. As the molecular weight of the complex increases, the $\mathrm{E}_{1 / 2}$ value decreases [53].

DNA binding studies of copper(II) complexes: The interaction of metal complexes with calf-thymus DNA was monitored by UV-visible spectroscopy. The absorption spectra of complexes were compared in the absence and in the presence of CT-DNA. In the presence of increasing amounts of DNA, the spectra of all complexes showed a strong decrease (Hypochromicity) in intensity with shift in absorption maxima towards lower (blue-shift) wavelengths.

Copper(II) complexes exhibit an intense absorption band around 352-341 nm which is attributed to metal-ligand charge transfer (MLCT) transitions. Absorption spectra were recorded in the range of 250-500 $\mathrm{nm}$. Electronic absorption spectral data upon addition of CT-DNA and binding constants of these complexes are given in the Table- 4 . The change in absorbance values with increasing amounts of CT-DNA was used to evaluate the intrinsic binding constant $\mathrm{K}_{\mathrm{b}}$, for the complexes. In the presence of increasing amounts of CT-DNA, the UV-visible absorption spectra of copper(II) complexes show bathochromic shift (blue shift) $\left(\lambda_{\max }: 2-3 \mathrm{~nm}\right)$. It is evident from the table, that all the complexes bind with DNA with high affinities and, the estimated binding constants are in the range $1-4 \times 10^{4} \mathrm{M}^{-1}$. This may be due to the presence of $\pi$-stacking of phenyl ring present in the Schiff base ligand. Typical absorption spectra of $\mathrm{Cu}_{2}\left(\mathrm{CH}_{3} \mathrm{COO}\right) \mathrm{HDP}$ in presence and in absence of DNA are shown in Fig. 8. The binding constants $\left(\mathrm{K}_{\mathrm{b}}\right)$ for DNA interaction of the complexes have been calculated by using the following equation:

$$
[D N A] /\left(\varepsilon_{\mathrm{a}}-\varepsilon_{\mathrm{f}}\right)=[\mathrm{DNA}] /\left(\varepsilon_{\mathrm{b}}-\varepsilon_{\mathrm{f}}\right)+1 / \mathrm{K}_{\mathrm{b}}\left(\varepsilon_{\mathrm{b}}-\varepsilon_{\mathrm{f}}\right)
$$

From Table-4, it is evident that complex with lower molecular weight i.e., $\mathrm{Cu}_{2}\left(\mathrm{CH}_{3} \mathrm{COO}\right) \mathrm{HDP}$ shows higher binding affinity towards DNA $\left(\mathrm{K}_{\mathrm{b}}=4.42 \times 10^{4} \mathrm{M}^{-1}\right)$ rather than the heavier copper complex $\mathrm{Cu}_{2}\left(\mathrm{CH}_{3} \mathrm{COO}\right) \mathrm{HDMP}\left(\mathrm{K}_{\mathrm{b}}=1.77 \times\right.$ $\left.10^{4} \mathrm{M}^{-1}\right)$.

DNA cleavage activities of copper(II) complexes: Nuclease activities of quinquedentate Schiff base ligands and their copper(II) compexes have been studied by agarose gel electrophoresis using pBR 322 plasmid DNA in Tris-HCl/ $\mathrm{NaCl}(50 \mathrm{mM} / 5$ $\mathrm{mM}$ ) buffer ( $\mathrm{pH} 7$ ) in the presence and absence of $\mathrm{H}_{2} \mathrm{O}_{2}$ after

TABLE-3

CYCLIC VOLTAMMETRIC DATA OF COPPER(II) COMPLEXES

\begin{tabular}{lcccccccc}
\hline \multicolumn{1}{c}{ Complex } & Redox couple & $\mathrm{E}_{\mathrm{pc}}(\mathrm{V})$ & $\mathrm{E}_{\mathrm{pa}}(\mathrm{V})$ & $\Delta \mathrm{E}_{\mathrm{p}}(\mathrm{mV})$ & $\mathrm{E}_{1 / 2}$ & $-\mathrm{i}_{\mathrm{c}} / \mathrm{i}_{\mathrm{a}}$ & $\log \mathrm{K}_{\mathrm{c}}^{\mathrm{a}}$ & $-\Delta \mathrm{G}^{\mathrm{ob}}$ \\
\hline $\mathrm{Cu}_{2}\left(\mathrm{CH}_{3} \mathrm{COO}\right) \mathrm{HDP}$ & $\mathrm{II} / \mathrm{I}$ & 0.296 & 0.425 & 129 & 0.360 & 1.224 & 0.260 & 1495 \\
$\mathrm{Cu}_{2}\left(\mathrm{CH}_{3} \mathrm{COO}\right) \mathrm{HDMP}$ & $\mathrm{II} / \mathrm{I}$ & 0.254 & 0.408 & 154 & 0.331 & 1.065 & 0.218 & 1252 \\
\hline
\end{tabular}

${ }^{\mathrm{a}} \log \mathrm{K}_{\mathrm{c}}=0.434 \mathrm{ZF} / \mathrm{RT} \Delta \mathrm{E}_{\mathrm{p}} ;{ }^{\mathrm{b}} \Delta \mathrm{G}^{\circ}=-2.303 \mathrm{RT} \log \mathrm{K}_{\mathrm{c}}$ 
TABLE-4

ELECTRONIC ABSORPTION DATA UPON ADDITION OF CT-DNA TO Cu(II) COMPLEXES

\begin{tabular}{|c|c|c|c|c|c|c|}
\hline \multirow{2}{*}{ Complex } & \multirow{2}{*}{ m.w. } & \multicolumn{2}{|c|}{$\lambda_{\max }(\mathrm{nm})$} & \multirow{2}{*}{$\Delta \lambda(\mathrm{nm})$} & \multirow{2}{*}{$\mathrm{H}(\%)$} & \multirow{2}{*}{$\mathrm{K}_{\mathrm{b}}\left(\mathrm{M}^{-1}\right)$} \\
\hline & & Free & Bound & & & \\
\hline $\mathrm{Cu}_{2}\left(\mathrm{CH}_{3} \mathrm{COO}\right) \mathrm{HDP}$ & 481 & 352 & 350 & 2 & 12.17 & $4.42 \times 10^{4}$ \\
\hline $\mathrm{Cu}_{2}\left(\mathrm{CH}_{3} \mathrm{COO}\right)$ HDMP & 509 & 344 & 341 & 3 & 8.74 & $1.77 \times 10^{4}$ \\
\hline
\end{tabular}

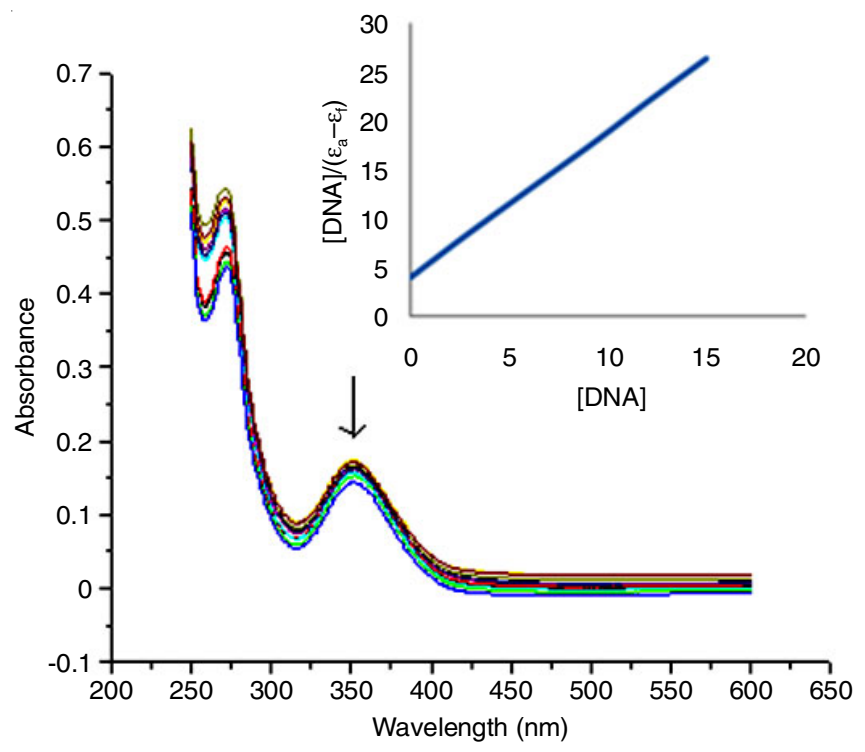

Fig. 8. Absorption spectra of $\mathrm{Cu}_{2}\left(\mathrm{CH}_{3} \mathrm{COO}\right) \mathrm{HDP}$ in the absence and in the presence of increasing concentration of CT-DNA; top most spectrum is recorded in the absence of DNA; A plot of $[\mathrm{DNA}] /\left(\varepsilon_{\mathrm{a}}-\varepsilon_{\mathrm{f}}\right)$ versus [DNA] is shown in the inset

$0.5 \mathrm{~h}$ incubation period at $37^{\circ} \mathrm{C}[22,28]$. At micromolar concentration, the ligands exhibit no significant activity in the absence or in the presence of the oxidant as shown in Fig. 9. But the copper(II) complexes show enhanced nuclease activity due to the presence of metal ions. Nuclease activity of complexes was also investigated in presence of free radical scavenger (DMSO), chelating agent (EDTA) and reducing agent DTT. Quantification of the gel afforded data of three forms is presented in Tables 5 and 6. From the data it is clear that $\mathrm{Cu}_{2}\left(\mathrm{CH}_{3} \mathrm{COO}\right) \mathrm{HDMP}$ has higher nuclease activity than the complex $\mathrm{Cu}_{2}\left(\mathrm{CH}_{3} \mathrm{COO}\right) \mathrm{HDP}$. In the absence of $\mathrm{H}_{2} \mathrm{O}_{2}$ the complexes cleaved supercoiled DNA (Form 1) into nicked DNA (Form II) (Fig. 10 lane 3 and 8). From Fig. 9 (lanes $4 \& 10$ ) and quantification data, it is evident that copper complexes cleave DNA more effectively in the presence of oxidant which may be due to hydroxyl radical $(\mathrm{OH})$ reaction with DNA. This is consistent with the increased production of hydroxyl radicals by cuprous ions similar to the well known Fenton reaction [54]. In presence of DTT (reducing agent) the cleavage activity of the complexes was further enhanced

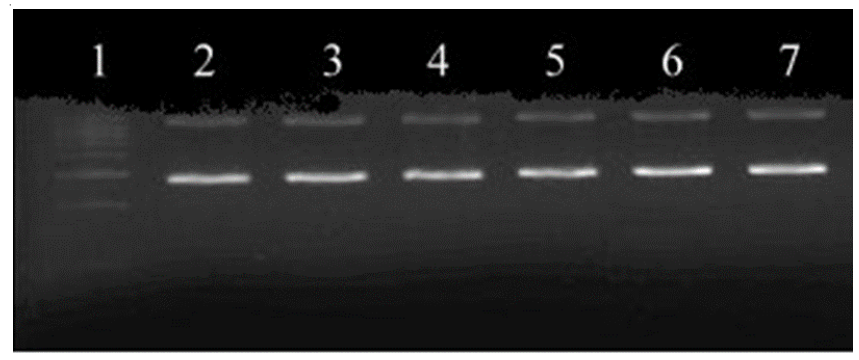

Fig. 9. Agarose gel $(0.8 \%)$ showing results of electrophoresis of $1 \mu \mathrm{L}$ of pBR 322 Plasmid DNA; $4 \mu \mathrm{L}$ of Tris- $\mathrm{HCl} / \mathrm{NaCl}(50 \mathrm{mM} / 5 \mathrm{mM})$ buffer (pH-7); $2 \mu \mathrm{L}$ of complex ligand in $\mathrm{DMF}\left(1 \times 10^{-3} \mathrm{M}\right) ; 11 \mu \mathrm{L}$ of sterilized water; $2 \mu \mathrm{L}$ of $\mathrm{H}_{2} \mathrm{O}_{2}$ (total volume $20 \mu \mathrm{L}$ ) were added, respectively, incubated at $37^{\circ} \mathrm{C}$ (30 min); Lane 1: $1 \mathrm{~kb}$ DNA Ladder; Lane 2: DNA control; Lane 3: DNA control $+\mathrm{H}_{2} \mathrm{O}_{2}$; Lane 4: $\mathrm{HDPH}_{3}$ $(100 \mu \mathrm{M})+$ DNA; Lane 5: $\mathrm{HDPH}_{3}(100 \mu \mathrm{M})+\mathrm{DNA}+\mathrm{H}_{2} \mathrm{O}_{2}$; Lane 6: $\mathrm{HDMPH}_{3}(100 \mu \mathrm{M})+\mathrm{DNA} ;$ Lane 7: $\mathrm{HDMPH}_{3}(100 \mu \mathrm{M})+\mathrm{DNA}$ $+\mathrm{H}_{2} \mathrm{O}_{2}$

(Fig. 10: lane 7 and 12), whereas the complexing agent EDTA could not show considerable effect over the DNA cleavage activity of the complexes.

\section{Conclusions}

- Physico-chemical and spectral studies suggest that the copper(II) complexes of quinquedentate ligands are acetato bridged dinuclear complexes with tetrahedral geometry.

- The complexes have covalent character as suggested by ESR spectral data.

- The cyclic voltammetric studies suggest that all the complexes undergo quasi-reversible one electron reduction. Repeated scans as well as various scan rates show that the complexes do not undergo any dissociation. The non-equivalent current intensity of cathodic and anodic peak indicates quasireversible behaviour of these complexes. Comparison of the $\mathrm{E}_{1 / 2}$ values of present copper(II) complexes with analogous nickel(II) complexes reveals that the complexes undergo more facile redox change which seems to be a requirement to the DNA cleavage.

- Ligands do not show any binding affinity towards CTDNA, but the affinity is greatly enhanced by the incorporation of metal ion in respective ligands. Copper(II) complexes derived from tridentate ligands show higher binding affinity which may

TABLE-5

SELECTED SC pBR322 DNA CLEAVAGE DATA OF LIGANDS IN Fig. 9

\begin{tabular}{clccc}
\hline \multirow{2}{*}{ Lane No. } & \multicolumn{1}{c}{ Reaction condition } & \multicolumn{2}{c}{ Percentage of } \\
\cline { 3 - 5 } & & Form I & Form II & Form III \\
\hline 2 & DNA & 95.17 & 4.83 & ND \\
3 & DNA $+\mathrm{H}_{2} \mathrm{O}_{2}(10 \mu \mathrm{M})$ & 94.38 & 5.62 & ND \\
4 & DNA $+\mathrm{HDPH}_{3}(62.5 \mu \mathrm{M})$ & 94.25 & 5.75 & ND \\
5 & DNA $+\mathrm{HDPH}_{3}(62.5 \mu \mathrm{M})+\mathrm{H}_{2} \mathrm{O}_{2}(10 \mu \mathrm{M})$ & 92.92 & 7.08 & ND \\
6 & DNA + $\mathrm{HDMPH}_{3}(62.5 \mu \mathrm{M})$ & 94.32 & 5.68 & ND \\
7 & DNA + $\mathrm{HDMPH}_{3}(62.5 \mu \mathrm{M})+\mathrm{H}_{2} \mathrm{O}_{2}(10 \mu \mathrm{M})$ & 91.48 & 8.52 & ND \\
\hline
\end{tabular}




\begin{tabular}{|c|c|c|c|c|}
\hline \multirow{3}{*}{ Lane No. } & \multicolumn{4}{|c|}{$\begin{array}{c}\text { TABLE-6 } \\
\text { SELECTED SC pBR322 DNA CLEAVAGE DATA OF COPPER COMPLEXES IN FIG. } 10\end{array}$} \\
\hline & \multirow{2}{*}{ Reaction condition } & \multicolumn{3}{|c|}{ Percentage of } \\
\hline & & Form I & Form II & Form III \\
\hline 1 & DNA & 97.18 & 2.82 & ND \\
\hline 2 & $\mathrm{DNA}+\mathrm{H}_{2} \mathrm{O}_{2}(10 \mu \mathrm{M})$ & 96.33 & 3.67 & ND \\
\hline 3 & $\mathrm{DNA}+\mathrm{Cu}_{2}\left(\mathrm{CH}_{3} \mathrm{COO}\right) \mathrm{HDP}(62.5 \mu \mathrm{M})$ & 88.25 & 11.75 & ND \\
\hline 4 & $\mathrm{DNA}+\mathrm{Cu}_{2}\left(\mathrm{CH}_{3} \mathrm{COO}\right) \mathrm{HDP}(62.5 \mu \mathrm{M})+\mathrm{H}_{2} \mathrm{O}_{2}(10 \mu \mathrm{M})$ & 32.98 & 67.02 & ND \\
\hline 5 & $\mathrm{DNA}+\mathrm{Cu}_{2}\left(\mathrm{CH}_{3} \mathrm{COO}\right) \mathrm{HDP}(62.5 \mu \mathrm{M})+\mathrm{DMSO}(10 \mu \mathrm{M})$ & 28.32 & 71.68 & ND \\
\hline 6 & $\mathrm{DNA}+\mathrm{Cu}_{2}\left(\mathrm{CH}_{3} \mathrm{COO}\right) \mathrm{HDP}(62.5 \mu \mathrm{M})+$ EDTA $(10 \mu \mathrm{M})$ & 71.48 & 30.52 & ND \\
\hline 7 & $\mathrm{DNA}+\mathrm{Cu}_{2}\left(\mathrm{CH}_{3} \mathrm{COO}\right) \mathrm{HDP}(62.5 \mu \mathrm{M})+\mathrm{DTT}(10 \mu \mathrm{M})$ & 22.13 & 77.87 & ND \\
\hline 8 & $\mathrm{DNA}+\mathrm{Cu}_{2}\left(\mathrm{CH}_{3} \mathrm{COO}\right) \mathrm{HDMP}(62.5 \mu \mathrm{M})$ & 41.79 & 58.21 & ND \\
\hline 9 & $\mathrm{DNA}+\mathrm{Cu}_{2}\left(\mathrm{CH}_{3} \mathrm{COO}\right) \mathrm{HDMP}(62.5 \mu \mathrm{M})+\mathrm{H}_{2} \mathrm{O}_{2}(10 \mu \mathrm{M})$ & 08.32 & 84.72 & 6.96 \\
\hline 10 & $\mathrm{DNA}+\mathrm{Cu}_{2}\left(\mathrm{CH}_{3} \mathrm{COO}\right) \mathrm{HDMP}(62.5 \mu \mathrm{M})+\mathrm{DMSO}(10 \mu \mathrm{M})$ & 09.26 & 89.66 & 1.08 \\
\hline 11 & $\mathrm{DNA}+\mathrm{Cu}_{2}\left(\mathrm{CH}_{3} \mathrm{COO}\right) \mathrm{HDMP}(62.5 \mu \mathrm{M})+\mathrm{EDTA}(10 \mu \mathrm{M})$ & 71.23 & 28.77 & ND \\
\hline 12 & $\mathrm{DNA}+\mathrm{Cu}_{2}\left(\mathrm{CH}_{3} \mathrm{COO}\right) \mathrm{HDMP}(62.5 \mu \mathrm{M})+\mathrm{DTT}(10 \mu \mathrm{M})$ & 20.13 & 89.87 & ND \\
\hline
\end{tabular}

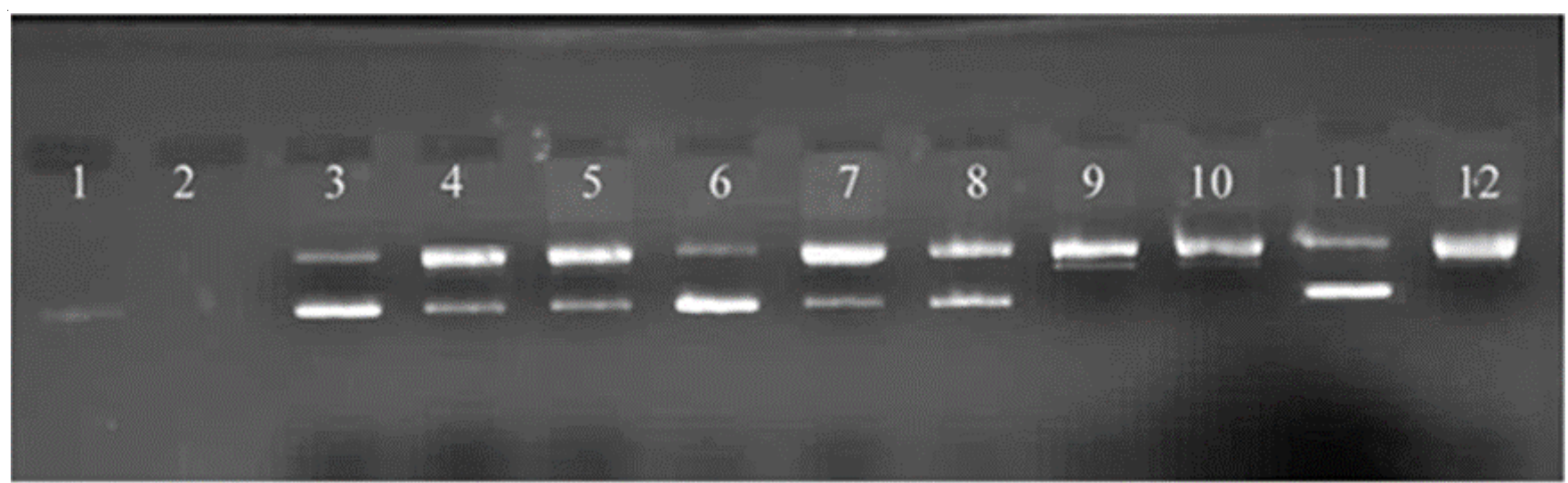

Fig. 10. Agarose gel $(0.8 \%)$ showing results of electrophoresis of $1 \mu \mathrm{L}$ of pBR 322 Plasmid DNA; $4 \mu \mathrm{L}$ of Tris- $\mathrm{HCl} / \mathrm{NaCl}(50 \mathrm{mM} / 5 \mathrm{mM})$ buffer (pH-7); $2 \mu \mathrm{L}$ of complex in $\mathrm{DMF}\left(1 \times 10^{-3} \mathrm{M}\right) ; 11 \mu \mathrm{L}$ of sterilized water; $2 \mu \mathrm{L}$ of $\mathrm{H}_{2} \mathrm{O}_{2}$ (total volume $20 \mu \mathrm{L}$ ) were added, respectively, incubated at $37{ }^{\circ} \mathrm{C}(30 \mathrm{~min}$ ); Lane 1: DNA control; Lane 2: DNA control $+\mathrm{H}_{2} \mathrm{O}_{2}$; Lane 3: $\mathrm{Cu}_{2}\left(\mathrm{CH}_{3} \mathrm{COO}\right) \mathrm{HDP}+\mathrm{DNA}$; Lane 4: $\mathrm{Cu}_{2}\left(\mathrm{CH}_{3} \mathrm{COO}\right) \mathrm{HDP}+\mathrm{DNA}+\mathrm{H}_{2} \mathrm{O}_{2} ; \mathrm{Lane}$ 5: $\mathrm{Cu}_{2}\left(\mathrm{CH}_{3} \mathrm{COO}\right) \mathrm{HDP}+$ DNA + DMSO; Lane 6: $\mathrm{Cu}_{2}\left(\mathrm{CH}_{3} \mathrm{COO}\right) \mathrm{HDP}+\mathrm{DNA}+\mathrm{EDTA}$; Lane 7: $\mathrm{Cu}_{2}\left(\mathrm{CH}_{3} \mathrm{COO}\right) \mathrm{HDP}$ + DNA+DTT; Lane 8: $\mathrm{Cu}_{2}\left(\mathrm{CH}_{3} \mathrm{COO}\right) \mathrm{HDMP}+\mathrm{DNA}$; Lane 9: $\mathrm{Cu}_{2}\left(\mathrm{CH}_{3} \mathrm{COO}\right) \mathrm{HDMP}+\mathrm{DNA}+\mathrm{H}_{2} \mathrm{O}_{2} ;$ Lane 10: $\mathrm{Cu}_{2}\left(\mathrm{CH}_{3} \mathrm{COO}\right) \mathrm{HDMP}+\mathrm{DNA}+\mathrm{DMSO}$ : Lane 11: $\mathrm{Cu}_{2}\left(\mathrm{CH}_{3} \mathrm{COO}\right) \mathrm{HDMP}+\mathrm{DNA}+\mathrm{EDTA} ;$ Lane $12: \mathrm{Cu}_{2}\left(\mathrm{CH}_{3} \mathrm{COO}\right) \mathrm{HDMP}+\mathrm{DNA}+\mathrm{DTT}$

be due to the presence of good leaving group $\left(\mathrm{H}_{2} \mathrm{O}\right)$, whereas the metal complexes with polymethylene backbones show least binding affinity towards CT-DNA because of steric hindrance of bulky ligands. Binding constants of nickel(II) complexes are found to be less when compared to those of copper(II) complexes.

- Ligands do not show significant nuclease activity, but their copper(II) complexes show remarkable activity. Copper(II) complexes show more nuclease activity in presence of an oxidizing agent $\left(\mathrm{H}_{2} \mathrm{O}_{2}\right)$.

\section{ACKNOWLEDGEMENTS}

One of the authors (M. Pragathi) is thankful to South Eastern Regional office (SERO), UGC, Hyderabad, India for awarding teacher fellowship under Faculty Development Programme and also for sanctioning minor research project (Sanction No. F MRP-4823/14(SERO-UGC). The authors are thankful to DST, New Delhi (Sanction No. SR/S1/IC-37/2007) for financial support and to SAIF, IIT-Madras for providing GC-MS spectra, SAIF, CDRI, Lucknow for providing ${ }^{1} \mathrm{H}$ NMR spectra and SAIF, IIT-Bombay for providing ESR spectral data.

\section{CONFLICT OF INTEREST}

The authors declare that there is no conflict of interests regarding the publication of this article.

\section{REFERENCES}

1. D.S. Sigman, A. Mazumder and D.M. Perrin, Chem. Rev., 93, 2295 (1993);

https://doi.org/10.1021/cr00022a011.

2. I. Saito and K. Nakatani, Bull. Chem. Soc. Jpn., 69, 3007 (1996); https://doi.org/10.1246/bcsj.69.3007.

3. S. Mahadevan and M. Palaniandavar, Inorg. Chem., 37, 693 (1998); https://doi.org/10.1021/ic961066r.

4. S. Borah, M.S. Melvin, N. Lindquist and R.A. Manderville, J. Am. Chem. Soc., 120, 4557 (1998); https://doi.org/10.1021/ja9729746.

5. J.A. Cowan, Curr. Opin. Chem. Biol., 5, 634 (2001); https://doi.org/10.1016/S1367-5931(01)00259-9.

6. J.R. Morrow and O. Iranzo, Curr. Opin. Chem. Biol., 8, 192 (2004); https://doi.org/10.1016/j.cbpa.2004.02.006.

7. F. Mancin, P. Scrimin, P. Tecilla and U. Tonellato, Chem. Commun., 20, 2540 (2005); https://doi.org/10.1039/b418164f.

8. E.L. Hegg and J.N. Burstyn, Coord. Chem. Rev., 173, 133 (1998); https://doi.org/10.1016/S0010-8545(98)00157-X.

9. P.R. Reddy, N. Raju, K.S. Rao and A. Shilpa, Indian J. Chem., 48A, 761 (2009).

10. S. Yamada, Coord. Chem. Rev., 190-192, 537 (1999); https://doi.org/10.1016/S0010-8545(99)00099-5.

11. P. Jain and K.K. Chaturvedi, J. Inorg. Nucl. Chem., 39, 901 (1977); https://doi.org/10.1016/0022-1902(77)80182-6.

12. R.D. Archer and B. Wang, Inorg. Chem., 29, 39 (1990); https://doi.org/10.1021/ic00326a009. 
13. D.E. Fenton and H. Okawa, J. Chem. Soc., Dalton Trans., 9, 1349 (1993); https://doi.org/10.1039/DT9930001349.

14. S. Chang, L.R. Jones, C. Wang, L.M. Henling and R.H. Grubbs, Organometallics, 17, 3460 (1998); https://doi.org/10.1021/om970910y.

15. Y. Nishida and S. Kida, J. Chem. Soc., Dalton Trans., 12, 2633 (1986); https://doi.org/10.1039/dt9860002633.

16. T.N. Sorrell, Tetrahedron, 45, 3 (1989); https://doi.org/10.1016/0040-4020(89)80033-X.

17. N. Kitajima and Y. Moro-oka, Chem. Rev., 94, 737 (1994); https://doi.org/10.1021/cr00027a010.

18. Q.L. Zhang, B.X. Zhu, L.F. Lindoy and G. Wei, Inorg. Chem. Commun., 11, 678 (2008); https://doi.org/10.1016/j.inoche.2008.03.006.

19. Y. Elerman, H. Kara and A. Elmali, Z. Naturforsch, 58a, 363 (2003).

20. K. Hussain Reddy, P. Sambasiva Reddy and P.R. Babu, Transition Met. Chem., 25, 154 (2000); https://doi.org/10.1023/A:1007027011216.

21. M.S.S. Babu, K.H. Reddy and P.G. Krishna, Polyhedron, 26, 572 (2007); https://doi.org/10.1016/i.poly.2006.08.026.

22. P. Murali Krishna, K. Hussain Reddy, J.P. Pandey and D. Siddavattam, Transition Met. Chem., 33, 661 (2008); https://doi.org/10.1007/s11243-008-9094-7.

23. P. Haribabu, Y.P. Patil, K.H. Reddy and M. Nethaji, Transition Metal Chem., 36, 867 (2011); https://doi.org/10.1007/s11243-011-9543-6..

24. K. Hussain Reddy, M.S. Surendra Babu, S.S. Babu and S. Dayananda, Indian J. Chem., 43A, 1233 (2004).

25. P. Hari Babu and K. Hussain Reddy, Indian J. Chem., 50A, 996 (2011).

26. K.H. Reddy, P.S. Reddy and P.R. Babu, Inorg. Biochem., 21, 169 (1999); https://doi.org/10.1016/S0162-0134(99)00188-9.

27. K.H. Reddy, P.S. Reddy and P.R. Babu, Transition Met. Chem., 25, 505 (2000); https://doi.org/10.1023/A:1007038514536.

28. H. Pagonda, P.P. Yogesh, H.R. Katreddi and N. Munirathinam, Inorg. Chim. Acta, 392, 478 (2012); https://doi.org/10.1016/j.ica.2012.03.042.

29. P. Hari Babu, Y. Patil, K.H. Reddy and M. Nethaji, Indian J. Chem., 52A, 327 (2013)

30. M. Pragathi and K. Hussain Reddy, Indian J. Chem., 52A, 845 (2013).

31. M. Pragathi and K. Hussain Reddy, Inorg. Chim. Acta, 413, 174 (2014); https://doi.org/10.1016/j.ica.2014.01.010.

32. W.J. Geary, Coord. Chem. Rev., 7, 81 (1971); https://doi.org/10.1016/S0010-8545(00)80009-0.

33. S. Anbu and M. Kandaswamy, Polyhedron, 30, 123 (2011); https://doi.org/10.1016/j.poly.2010.09.041.

34. A.B.P. Lever, Inorganic Electronic Spectroscopy, Elsevier: Amsterdam, edn. 2 (1984).
35. K.H. Reddy and Y. Lingappa, Transition Met. Chem., 19, 487 (1994); https://doi.org/10.1007/BF00136356.

36. S.K. Sahni, S.K. Sangal, S.P. Gupta and V.B. Rana, J. Inorg. Nucl. Chem., 39, 1098 (1977); https://doi.org/10.1016/0022-1902(77)80280-7.

37. N. Tirumavalavan, S.M. Rayappan, P. Akilan and M. Kandaswamy, Indian J. Chem. Technol., 11, 29 (2004).

38. S.G. Teoh, G.Y. Yeap, C.C. Loh, L.W. Foong, B. Teo and H.K. Fun, Polyhedron, 16, 2213 (1997); https://doi.org/10.1016/S0277-5387(96)00546-3.

39. G.B. Deacon and R.J. Philips, Coord. Chem. Rev., 33, 227 (1980); https://doi.org/10.1016/S0010-8545(00)80455-5.

40. K. Nakamoto, Infrared and Raman Spectra of Inorganic and Coordination Compounds, Wiley Interscience: New York (1978)

41. D. Kivelson and R. Neiman, J. Chem. Phys., 35, 149 (1961); https://doi.org/10.1063/1.1731880.

42. N. Raman, A. Kulandaisamy and K. Jeyasubramanian, Indian J. Chem., 41A, 942 (2002).

43. S.M. Mamdoush, S.A. Abou El Enein, H.M. Kamel, Indian J. Chem., 41A, 297 (2002)

44. V. Philip, V. Suni, M.R.P. Kurup and M. Nethaji, Polyhedron, 24, 1133 (2005); https://doi.org/10.1016/j.poly.2005.03.064.

45. B. Singh, B.P. Yadava and R.C. Agarwal, Indian J. Chem., 23A, 441 (1984)

46. B.J. Hathaway and A.A.G. Tomlinson, Coord. Chem. Rev., 5, 1 (1970); https://doi.org/10.1016/S0010-8545(00)80073-9.

47. A.H. Maki and B.R. McGarvey, J. Chem. Phys., 29, 31 (1958); https://doi.org/10.1063/1.1744456.

48. B.J. Hathaway and D.E. Billing, Coord. Chem. Rev., 5, 143 (1970); https://doi.org/10.1016/S0010-8545(00)80135-6.

49. B.J. Hathaway, J. Struct. Bonding, 14, 49 (1971) https://doi.org/10.1007/BFb0016871.

50. E.B. Seena and M.R.P. Kurup, Polyhedron, 26, 829 (2007); https://doi.org/10.1016/j.poly.2006.09.040.

51. A.S. Kumbhar, S.B. Padhye, D.X. West and A.E. Liberta, Transition Metal Chem., 16, 276 (1991); https://doi.org/10.1007/BF01032852.

52. S. Usha and M. Palaniandavar, J. Chem. Soc., Dalton Trans., 2277 (1994); https://doi.org/10.1039/DT9940002277.

53. P. Muralikrishna, Ph.D. Thesis, Investigations on Nuclease Activity of Metal Complexes of Ligands Derived from the Constituents of Some Indian Spices, S.K. University, Anantapur, India (2007).

54. A. Hangan, A. Bodoki, L. Oprean, G. Alzuet, M. Liu-González and J. Borrás, Polyhedron, 29, 1305 (2010); https://doi.org/10.1016/j.poly.2009.12.030. 